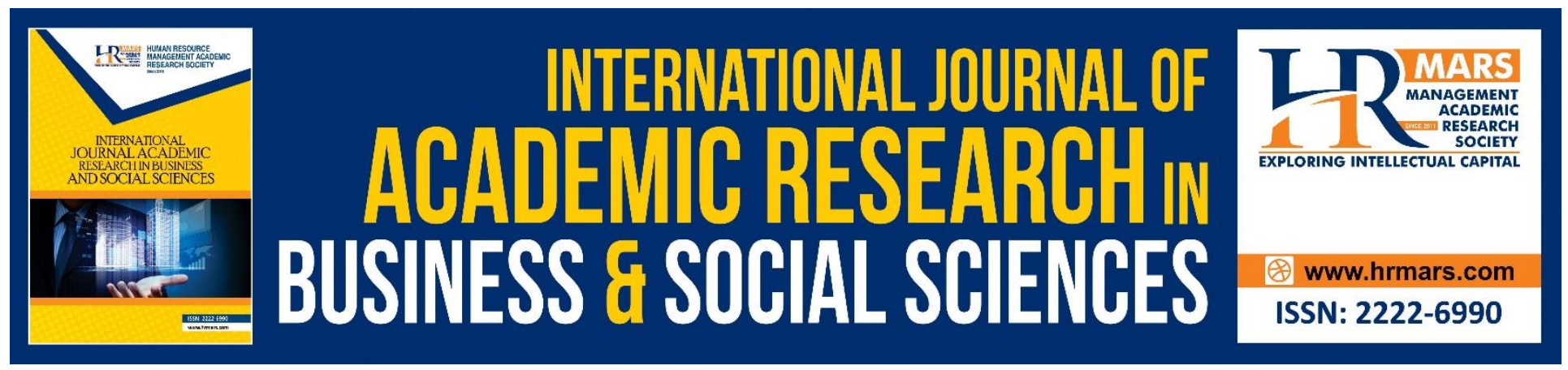

\title{
Waqf Reporting: A Modified Integrated Reporting for Sustainable Islamic Social Finance
}

Noorhayati Mansor, Amira Jamil, Asniati Bahari

To Link this Article: http://dx.doi.org/10.6007/IJARBSS/v8-i12/5069

DOI: $10.6007 /$ IJARBSS/v8-i12/5069

Received: 11 Nov 2018, Revised: 19 Dec 2018, Accepted: 24 Dec 2018

Published Online: 29 Dec 2018

In-Text Citation: (Mansor, Jamil, \& Bahari, 2018)

To Cite this Article: Mansor, N., Jamil, A., \& Bahari, A. (2018). Waqf Reporting: A Modified Integrated Reporting for Sustainable Islamic Social Finance. International Journal of Academic Research in Business and Social Sciences, 8(12), 742-754.

Copyright: (c) 2018 The Author(s)

Published by Human Resource Management Academic Research Society (www.hrmars.com)

This article is published under the Creative Commons Attribution (CC BY 4.0) license. Anyone may reproduce, distribute, translate and create derivative works of this article (for both commercial and non-commercial purposes), subject to full attribution to the original publication and authors. The full terms of this license may be seen

at: http://creativecommons.org/licences/by/4.0/legalcode

Vol. 8, No. 12, 2018, Pg. 742 - 754

http://hrmars.com/index.php/pages/detail/IJARBSS

JOURNAL HOMEPAGE

Full Terms \& Conditions of access and use can be found at http://hrmars.com/index.php/pages/detail/publication-ethics 


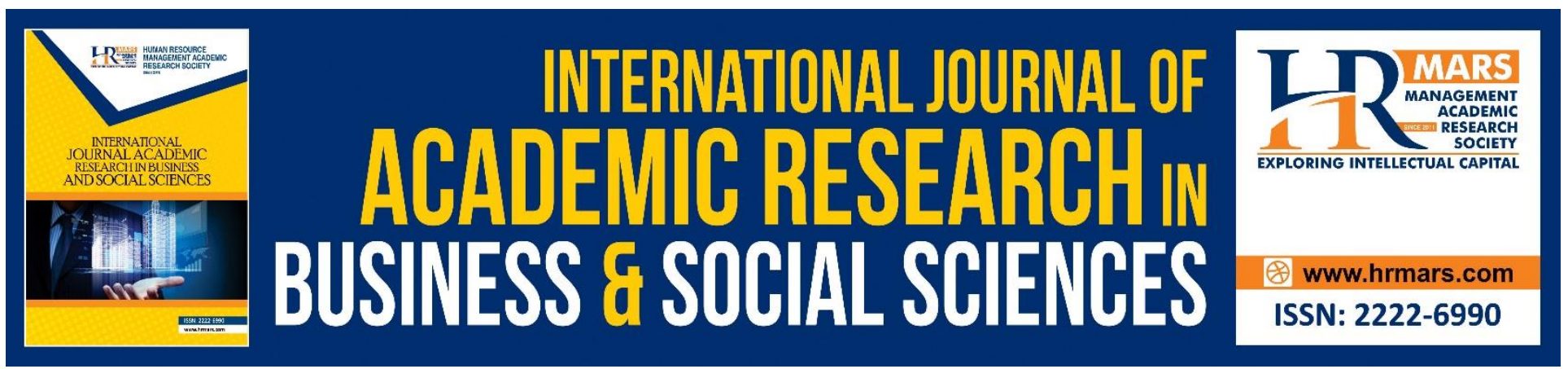

\title{
Waqf Reporting: A Modified Integrated Reporting for Sustainable Islamic Social Finance
}

\author{
Noorhayati Mansor \\ Faculty of Economics and Management Sciences, Universiti Sultan Zainal Abidin,Terengganu, \\ Malaysia. \\ Email: nhayatimansor@unisza.edu.my
}

Amira Jamil

Faculty of Entrepreneurship and Business, Universiti Malaysia Kelantan, Malaysia

Email: amira@umk.edu.my

Asniati Bahari

Faculty of Economics, Universitas Andalas, Padang, Indonesia

Email: Asniati.bahari@gmail.com

\begin{abstract}
The increasing growth of waqf activities in recent years makes it timely to study the accounting and reporting practices for this important economic sector. Waqf institutions are generally voluntarily established with emphasis on acquiring waqf assets and cash contributions to fund activities. Generally, less attention is given to the accounting and reporting aspects. Today, the global accounting practice is moving towards reporting of multiple capitals to create value for sustainable business. Introduced in 2013 and known as integrated reporting, this approach is relatively new to most part of the world including Malaysia. The approach integrates six types of capitals categorized as human, intellectual, social, manufactured, natural and financial, linked to business model and strategy in value creation. It expands the traditional reporting which stresses on past financial performance, to future, strategy-based focus. This research reviews the literature on waqf accounting and reporting practices and discusses the drawbacks of the conventional accounting system for Islamic social finance. The study then highlights the new integrated reporting and discusses its applicability in waqf reporting which is based on the Islamic reporting and accountability. The proposed Integrated Waqf Reporting System (IWRS) adopts a long-term perspective, linking organizational performance to business model and strategy and, providing information on Social, Intellectual, Relational, Awqaf and Human (SIRAH) capitals. The IWRS highlights the principle of stakeholders-inclusiveness and assist the public and potential donors in determining the long-term
\end{abstract}


INTERNATIONAL JOURNAL OF ACADEMIC RESEARCH IN BUSINESS AND SOCIAL SCIENCES Vol. 8, No. 12, Dec, 2018, E-ISSN: 2222-6990 @ 2018 HRMARS

performance of waqf institutions and enhance the social support and sustainability of Islamic social finance.

Keywords: Integrated Reporting; waqf reporting; financial accounting; integrated waqf reporting system; Islamic social financing.

\section{Introduction}

Waqf is a highly respectable religious practice among Muslims where wealth is voluntarily and legally transferred by a donor (waqif) to an administrator or a trustee (mutawalli). The main objective of waqf is to help improve the social conditions of the less fortunate community members through sharing and donating of one's wealth and contribute toward the growth of Islamic social finance. The transfer involves physical assets or cash, permanently or for a predetermined period. The practice is not limited to individuals. Today, increasing number of large corporations have pledged their support and contributions to waqf-based organizations. At the same time many public entities including colleges and universities are actively seeking waqf contributions from wealthy individuals and private businesses. Many publicly owned companies are also contributing cash waqf as part of their corporate social responsibility. Cash and all waqf assets have made possible various social transformations and economic development to improve the livelihood and welfare of the deserving Muslim community.

Waqf falls under charitable activity and income generated through utilizing waqf assets is distributed to the stated beneficiaries (mawquf alaih) according to the intended purposes (Malaysian Accounting Standards Board, 2014). Waqf administration has an infinite term and accountability of the assets. As part of a religious practice, a waqf trustee is accountable to Allah s.w.t. and to other individuals especially the direct beneficiaries and the community. This dual accountability relationship also ensures that the trustees and administrators do not only use the assets to their fullest potentials but also to avoid losses and value reduction. Today, public and private entities, government or non-profit organizations could also be appointed to serve as trustees whereas, in the past, only individuals were involved (Osman, 2010).

The current waqf reporting practice is based on the conventional accounting system and has inherent drawbacks. Firstly, the coverage of the reporting is rather short-sighted since it recognises and reports only annual financial information (Masruki et al., 2017). Issues especially involving socioeconomic and environmental cannot be fully addressed using financial figures and thus, is often left out or not comprehensively mentioned in the annual reporting of waqf institutions. Secondly, only economic events which could be monetarily valued were included (Ibrahim, 2000) and thus, making the reports less useful for planning purposes (Mansor \& Mamat, 2017). Thirdly, regarding conciseness, the reporting tends to be long and complicated (KPMG International, 2011) focusing on financial information using technical jargons (Mansor \& Mamat, 2017) and consequently, reduces the understanding and usefulness of the reports. Overall, the conventional reporting is less sensitive to waqf stakeholders and the public. Accordingly, a new reporting approach should be practiced to ensure the growth, support and sustainability of waqf institutions. 
Integrated reporting was introduced by the International Integrated Reporting Council (IIRC) in 2013 based on integrated thinking to ensure the relevance and usefulness of reporting. Nonetheless, it is still not widely implemented in Malaysia even though many organizations have pledged to adopt it. The current target is to have 100 businesses practicing the new reporting by 2019. The revised Malaysian Code on Corporate Governance which was launched on 26 April 2017 also supports its adoption to enhance information quality, transparency and accountability (Securities Commission Malaysia, 2017).

Even though the reporting was designed for the private sector, it is also relevant to the public and not-for-profit sectors (as stated in Paragraph 1.4 of the International Integrated Reporting Framework) and thus, applicable to waqf institutions as well. The integrated reporting introduces value creation and capital preservation and matches well with the mutawalli's responsibilities in waqf organizations (Mansor, Jamil, \& Bahari, 2017). Capitals are classified into six categories which are human, intellectual, social, manufactured, natural and financial. This study reviews the current waqf reporting and discusses reporting issues related to the conventional reporting. A new Integrated Waqf Reporting System (IWRS) is proposed based on Islamic reporting, accountability and social responsibility. The study contributes to the development of waqf reporting practices in line with the global accounting practice. This research concludes with suggestions to strengthen and promote the practice of waqf to strengthen the Islamic social finance.

\section{Literature Review \\ Current Waqf Reporting Issues}

As a religious entity receiving and relying on funds from public donors, waqf institutions have the duty to report their performance in managing the waqf assets to a wide range of stakeholders. Providing timely, transparent, informative periodic reports is crucial to the current and potential donors to support the activities of the institutions. Studies continue to show that waqf management is still inefficient and ineffective with recurring problems such as under-developed and idle waqf lands and properties, inability to generate income and mismanagement (Ihsan \& Adnan, 2009; Ihsan \& Ayedh, 2015; Mohd Puad, Jamlus Rafdi, \& Shahar, 2014; Osman, 2010). For example, in Malaysia, only 2 per cent of nearly 13,500 hectares of waqf land has been developed while the remaining $92 \%$ is still idle. Cases of mismanaged waqf assets are common (Utusan Online, 23 February 2018; Sinar Online, 7 January 2014) including widespread of misuse of public funds and management misconduct (Berita Mediacorp, 16 November 2017; Sinar Harian, 29 June 2018).

The poor management of waqf institutions could be due to limited regulations and enforcement mechanisms including improper accounting and reporting practices (Ramli, Fahmi, Darus, \& Ismail, 2018). Today, public concerns together with economic, social, environmental and technological factors are putting pressure on the waqf entities to become more sensitive to the accounting and reporting for the use of publicly collected funds (Siraj \& Karbhari, 2014). One of the ways is through disclosure of information concerning the use and distributions of funds in order to strengthen the quality of reporting and gain continuous support organizational sustainability. 
Unfavourable issues in waqf reporting such as incomparable, unreliable, incomplete and unverifiable reports are commonly document in past studies. Firstly, the reporting is incomparable due to variations in the practice among waqf organisations due to differences in formations of these institutions (Malaysian Accounting Standards Board, 2014). The waqf entities were established as corporation, non-profit-organisation, public sector entities and foundation, and thus, bound to different or non-existence reporting requirement and guidelines (Ihsan \& Adnan, 2009; Masruki \& Shafii, 2013). Secondly, the current waqf reporting could be unreliable as the reports coverage are very limited and out-dated (Ihsan \& Ibrahim, 2011; Mustaffha \& Zainal, 2016; Siraj, 2012). In addition, the reporting is incomplete and focuses mostly on financial information disclosure and not the nonfinancial information (Masruki et al., 2017).

Though financial reporting is often used for evaluation of current and past performance, the report is inadequate (British Universities Finance Directors Group, 2017) to communicate the operations, performance, values, capitals utilisation and benefits distribution. According to Torres \& Pina (2003) disclosure of financial capital does not deliver sufficient information about the institutions and backwards-looking. Thus, it is challenging for the stakeholders and donors to use the report for decision-making (Mansor \& Mamat, 2017). Thirdly, some institutions never publish their reports or make them available on their websites (Sulaiman, Adnan, \& Nor, 2009). This is contradictory to their status as social organisations, collecting donations and relying on the public for capital and support. Rather, these social organisations should be accountable to the public at large, hence, demonstrate their transparency and accountability through various reporting mediums.

Enforcement of waqf accounting and reporting system is crucial to the discharge of accountability to the stakeholders (e.g., Ihsan \& Adnan, 2009; Ihsan \& Ibrahim, 2011; Masruki \& Shafii, 2013; Yaacob, Petra, Sumardi, \& Nahar, 2013; Zain et al., 2012). At present, there is a lack of non-financial information disclosure in non-profit financial reporting (Azmi \& Hanifa, 2015; Mustaffha \& Zainal, 2016) and thus, do not comply with the objectives of Islamic accounting which is to promote fairness, accountability and transparency in society.

\section{Drawback of Conventional Reporting for Waqf Institutions}

The conventional waqf reporting is ineffective for its purpose due to the following reasons. Firstly, the approach is governed by a rules-based system and adopts an annual or short-term perspective. The system provides standardized rules and principles for financial statements preparations. Thus, its main advantage is that it reduces ambiguity and increases reporting accuracy. On the other hand, it lacks flexibility to allow for variations in business models and strategies. The integrated reporting is principles-based and focuses on the value creation using multiple capitals and thus, practical for waqf institutions.

The current reporting approach is also inappropriate for achieving the objectives of Islamic social finance since it is based on the capitalism and individualism perspectives. The emphasis is more on profit maximization and less on the social and environmental aspects while the primary purpose of reporting in Islam is to discharge one's accountability to Allah (Adnan, 1996; Hameed, 2000). The reporting basis of short-term annual performance is also inappropriate in the case of waqf 
INTERNATIONAL JOURNAL OF ACADEMIC RESEARCH IN BUSINESS AND SOCIAL SCIENCES Vol. 8, No. 12, Dec, 2018, E-ISSN: 2222-6990 @ 2018 HRMARS

management since the perspective of waqf is infinite. At the same time, donors of the waqf assets are concerned with value preservation and growth to ensure organizational sustainability rather than yearly profits (Cordery \& Morley, 2005).

The conventional reporting also focuses on the disclosures of financial information that is mainly retrospective and based on the organization's current and past performance (Perrini, 2006). The report plays a limited role in discharging accountability as it delivers insufficient disclosure of success, performance and impact of the organisation on the stakeholders and the environment (Torres \& Pina, 2003). Thus, it is very challenging for the stakeholders to use the report in doing future planning (Mansor \& Mamat, 2017).

The conventional reporting does not provide comprehensive potentials of waqf assets to the users since the report does not convey the management's strategic vision and projections on value creation (Hutton, 2004). In practice, waqf activities involve more than economic events with direct financial outcome. Most important of all is the use of natural resources and human labour with nonquantifiable effects on social and environmental aspects. Thus, disclosures of qualitative data would also be important for stakeholders to continue support for the waqf organizations (Cordery \& Morley, 2005). Furthermore, the current financial reporting is not readily understood without technical competency and familiarity with the accounting standards (Mansor \& Mamat, 2017).

Hence, a modified integrated reporting for waqf institutions would serve the information needs of the stakeholers. In particular, the disclosures would require additional information on unproductive or idle waqf assets in order to assure completeness in reporting. Instead of the six capitals identified under the integrated reporting the modified waqf reporting would add a disclosure on the awqaf capital. Thus, the reporting would provide information on Social, Intellectual, Relational, Awqaf and Human (SIRAH) capitals, in addition to the financial capital. The new waqf reporting would provide more comprehensive information for the stakeholders to assess the future growth potential of the waqf assets than the current approach. Consistent with the long-term perspective, reporting IHSAN capitals would show how the various capitals are utilized and affected to enhance the sustainability of waqf as an instrument of Islamic social finance.

\section{Accountability from the Islamic Perspective}

One of the main aims of accounting and reporting system is to assure trustworthiness through the auditing process. In the conventional approach, accountability requires those with delegated authority to be answerable for the outcomes of the use of resources to achieve certain ends (Sinclair, 1995). Gray, Dey, Owen, Evans, \& Zadek (1997) on the other hand, define accountability as "the duty to provide an account of the actions for which one is held responsible". Nonetheless, these definitions fail to demonstrate accountability from the Islamic perspective where the ultimate accountability (taklif) is to Allah and all actions will be counted on the Hereafter. This is demonstrated in the verse of the Al-Quran: 
INTERNATIONAL JOURNAL OF ACADEMIC RESEARCH IN BUSINESS AND SOCIAL SCIENCES Vol. 8, No. 12, Dec, 2018, E-ISSN: 2222-6990 @ 2018 HRMARS

"To Allah belongs all that is in the heavens and on earth. Whether you show what is in your minds or conceal it, Allah will call you to account for it" (Quran, Al-Baqarah 2:284)

Ibrahim (2000) proposes dual accountability or Islamic accountability that includes accountability to Allah (hablun min Allah) and also accountability to individuals (hablun min an-nas). Muslim believes that all resources available are created by Allah and individual as a trustee (khalifah) is accountable to Allah for all of their actions in utilising the resources (Osman, 2010). This is the other dimension that is not captured under the conventional accountability. Similar to conventional perspective, an individual should be accountable to other individuals, for example, the management and capital providers should be accountable for all of their actions within the organisation (such as employees) and outside the organisation (such as the community, society and environment) (Lewis, 2006).

Based on Islamic accountability, waqf institution as Islamic organisation that is established to serve the public interest should be accountable to the society (Lewis, 2006) and the society has the right to know the effects of the organisation's operation, its sustainability status, performance and also whether the organisation is operated within the Shariah regulation. Therefore, preparation of transparent and comprehensive annual report by waqf institution is crucial to fulfilling this accountability and must not be limited to only financial information disclosure (Cordery \& Morley, 2005).

Lewis (2006) highlighted principles of Islamic reporting which are applicable for waqf reporting which are relevance, material, understandable and reliable. The word relevance was discussed six times in the Al-Quran and referred to as disclosure of all facts (Surah Al-Baqarah, verse 71). Thus, reporting both financial and non-financial information is desirable for the benefits of users to understand how waqf assets were utilized to serve the objectives and wishes of the waqif. According to Mansor, Jamil and Bahari (2018) all Muslim countries should form mutual interest and cooperation in promoting a new framework for waqf reporting through establishing an International Waqf Reporting Board (IWRB).

\section{The Modified Integrated Waqf Reporting System}

Baydoun \& Willet (2000) categorize Islamic reporting in two parts: (i) full disclosure; and (ii) social accountability. These two principles are interrelated because the intention is to inform users of important transactions in the course of serving Allah s.w.t. (Othman \& Thani, 2010). According to Ibrahim \& Yaya (2005) Islamic reporting is guided by three main objectives. First is to provide useful information to users and second, to safeguard assets and enhance managerial and productive capabilities by complying with established goals. The third objective is to undertake actions and provide appropriate accounts of these actions.

The conventional financial statements are designed mostly for compliance purposes but lacking information on how organizations create value for sustainable business. Integrated reporting, on the other hand, stresses on aligning organizational strategies with financial information to explain how 
resources create value in the short-term, medium-term and long-term (KPMG International, 2011). The integrated reporting approach shifts beyond compliance-based reporting to commitment of transparency by applying complete disclosure of issues, whether positive and negative. Besides, unlike the conventional reporting, integrated reporting uphold the materiality principle that is strongly linked to stakeholder-inclusiveness principle (The Integrated Reporting Committee, 2011) where the reporting should be more responsive to stakeholders' needs and demands.

Comparing the objectives of integrated reporting with those of Islamic reporting, three similarities emerge. Firstly, both of them focus on decision usefulness through enhancing information quality for improved business decisions. However, in contrast to integrated reporting, the Islamic reporting uses the Shariah principles as the basis to making decisions. Secondly, they both stress on fulfilling the stewardship and accountability towards the stakeholders. Under the integrated reporting this is achieved through linking the six capitals and business strategy. The Islamic reporting promotes the stewardship by encouraging compliance with organizational policies and goals. Thirdly, the two systems require integrated thinking and long-term perspective in promoting sustainable business. In contrast to the integrated reporting, the Islamic reporting has an added dimension of accountability to Allah. Based on the common objectives, the modified integrated reporting in combination with Islamic accounting is very appropriate for the proposed waqf reporting.

The proposed Integrated Waqf Reporting System (IWRS) also adopts the principles-based framework instead of the rules-based approach. The former allows for increased flexibility for these social institutions to design their unique reports. Therefore, the IWRS could be tailored to the specific waqf organisation's goals and activities since there are various forms of waqf institutions such as corporation, foundation, government agencies and non-profit organisation with diverse goals and activities. The flexibility, however, does not imply a lack of comparability. Presentation basis has to be determined from the beginning including the type of capitals to be reported. At the minimum the integrated reporting should include organisational overview and its external environment, the governance structure, the business model, risk and opportunities, how they affect value creation, performance and achievement of strategic objectives and, trend and challenges as well as their implications.

The main purpose of IWRS is to produce a balanced reporting, concise, reliable, relevant and free of material errors. The integrated reporting is suitable for these institutions since they are socially financed and less profit-oriented. Accordingly, the financial capital should be of lower priority than the other capitals. The non-financial capitals include relational capital (such as the relationship with other institutions, corporations and governments), social and human capital (from social activities), environment or natural capital and also reputational capital. Disclosure of these capitals could provide a comprehensive picture of their operations and performance. Since they administer donated assets based on trustworthiness, they are not bound to officially report to the donors. In fact, the donors (waqif) are divorced from the waqf assets once the assets were transferred to the institutions. However, reporting how the waqf capital was used and how the society benefits could motivate the donors to continue the practice of waqf. Thus, the new reporting should also include 
the awqaf capital in addition to the manufactured capital. Even though the integrated reporting recommends six capitals, each waqf institutions should decide the capitals to be reported. The proposed IWRS could also overcome the criticism of short-term focus of conventional financial reporting since waqf is meant for perpetuity.

Integrated reporting gives high attention to the nature of value and value creation. Value could include the total of all the capitals, the derived benefits, the market value or cash flows and the level of achievement of organizational objectives. The new framework provides the opportunity for waqf institutions to explain how the principal value of waqf assets is protected and managed. Integrated reporting preparation involves judgment and summary information on how organizations establish the materiality limits to be disclosed together with the description of the scope of reporting. Measurement methods across different reports should be consistent and the selection of performance indicators should be described. The information disclosed, however, should be sufficient and balanced to avoid a significant loss of competitive advantage due to the disclosure.

Through IWRS, every waqf organization is forced to clearly identify its sustainable business model. This model acts as the driver of activities and forms the foundation for strategies. Every strategy that involves significant short term and long term risks should be disclosed in the IWRS. Value-added activities also need to be balanced and driven by effective and efficient governance system. Therefore, the implementation of IWRS will ensure that waqf organizations pay serious attention to their governance matter since the structure and performance of governance would also be reported together with other main capitals and performance indicators. With clearly stated objectives properly linked to the strategies and performance measures, IWRS can fulfil the demand for accountability especially for the beneficiaries and waqif (Cordery \& Morley, 2005). The development and implementation of IWRS is a proactive and best attempt to enhance the accountability of the waqf to Allah and the society. As Islamic-based and socially funded organizations waqf institutions should strive for optimum transparency and accountability in reporting to inform the society fairly. According to Aman (2016) Islamic entities should report significant information about their operations including the information that may have an unfavourable effects to their reputation.

\section{Conclusion and Recommendation}

Waqf entities were established with the broad objectives to benefit the society within the Islamic social finance. Their perspective is very long-term or perpetuity in serving the intended beneficiaries. As non-profit, charitable, socially financed entities they currently suffer from weak and inefficient accounting and reporting practice. Their main priority and focus is short-term since there is a constant pressure to obtain funding, especially cash to support operations. In most cases, the awqaf are not fully utilized because of the nature of assets and the allowable or prescribed purposes. For example, most of the waqf land is meant for building mosques and religious schools. Thus, the land remains idle without any activities that could generate cash flow for operations until sufficient fund is available to construct the mosques or schools. Furthermore, the accounting and reporting practice are usually left unquestioned since the general impression is that the activities are voluntary and the institutions are not accountable to the original donors. 
Accordingly, this study suggests a modified reporting framework for waqf operations based on the new global practice of integrated reporting. Challenges in using the conventional financial reporting were reviewed in relation to the conventional framework. Instead of past achievements the emphasis for waqf reporting should be on the future value creation using multiple capitals which are linked to strategy and business models. Regardless of their legal forms, the main goal of these entities is to capitalize and utilize the waqf assets as one of the main resources in generating value and benefits for the intended beneficiaries.

The Islamic concept of dual accountability is applied in the combined integrated and Islamic reporting. IWRS shall overcome the drawbacks of the conventional financial reporting. Since waqf assets would be dominant, IWRS would report awqaf assets as one of the non-financial capitals. Thus, this study recommends the reporting of Social, Intellectual, Relational, Awqaf and Human (SIRAH) capitals in addition to the financial capital. The new IWRS will reduce the less understood technical jargons associated with traditional reporting and become more user friendly for the stakeholders. The Islamic approach reduces the profit-maximization emphasis to that of safeguarding the awqaf and fulfilling the wishes of the waqifs. Accordingly, the IWRS would further improve reporting quality and efficiency, stakeholders' satisfaction and public participation.

The goal of IWRS is not only to increase disclosure but to convey useful information and allow for greater understanding and thus, continuous public and all stakeholders' participation. The proposed improvement in waqf reporting, however, must also be supported by leveraging on innovations in technology. The current move to cloud accounting and auditing, artificial intelligence, autonomous robotics and data analytics would be part of the implementation effort in addition to further research and discussions in this important growth sector of the global economy.

\section{*Corresponding Author:}

Noorhayati Mansor

Faculty of Economics and Management Sciences, Universiti Sultan Zainal Abidin, 21300 Kuala Terengganu, Terengganu, Malaysia.

Email: nhayatimansor@unisza.edu.my

\section{References}

Adams, S., \& Simnett, R. (2011). Integrated reporting : An opportunity for Australia ' s not-for- profit sector. Australian Accounting Review, 5825, 21(3), 292-301.

Adnan, M. A. (1996). An investigation of accounting concepts and practices in Islamic banks: The cases of Bank Islam Malaysia Berhad and Bank Muamalat Indonesia. University of Wollongong Research Online. University of Wollongong.

Aman, Z. (2016). Corporate sustainability reporting from Islamic perspectives. In Proceeding of the 2nd International Conference on Economics \& Banking 2016 (Vol. 2nd ICEB, pp. 1-8). Kajang: Kolej 
INTERNATIONAL JOURNAL OF ACADEMIC RESEARCH IN BUSINESS AND SOCIAL SCIENCES Vol. 8, No. 12, Dec, 2018, E-ISSN: 2222-6990 @ 2018 HRMARS

Universiti Islam Antarabangsa Selangor (KUIS).

Azmi, A. C., \& Hanifa, M. H. (2015). The Sharia-compliance of financial reporting practices: a case study on Waqf. Journal of Islamic Accounting and Business Research, 6(1), 55-72.

Baydoun, N., \& Willet, R. (2000). Islamic Corporate Reports. Abacus, 36(1), 71-90.

British Universities Finance Directors Group. (2017). Integrated reporting in four British universities. Cordery, C. J., \& Morley, R. F. (2005). Hegemony, stakeholder salience and the construction of accountability in the charity sector. Working Paper No. 25.

Dahlan, N. K., Yaa'kub, N. I., Hamid, M. A., \& Palil, M. R. (2014). Waqf (Endowment) practice in Malaysian society. International Journal of Islamic Thought, 5(June), 56-61.

Gray, R., Dey, C., Owen, D. L., Evans, R., \& Zadek, S. (1997). Struggling with the praxis of social accounting: stakeholders, accountability, audits and procedures. Accounting, Auditing \& Accountability Journal, 10(3), 325-364.

Hameed, S. H. M. (2000). The need for Islamic Accounting: Perceptions of its objectives and characteristics of Islamic Accounting: Perceptions of Malaysian Muslim accountants and accounting academics. UK: University of Dundee.

Hameed, S. H. M., \& Yaya, R. (2003). The future of Islamic corporate reporting: Lessons from alternative western accounting reports. In International Conference on Quality Financial Reporting and Corporate Governance.

Hameed, S. H. M., \& Yaya, R. (2005). The emerging issues on the objectives and characteristics of Islamic Accounting for Islamic business organisations. Malaysian Accounting Review, 4(1), 75-92. Hutton, A. (2004). Beyond financial reporting - An integrated approach to disclosure. Journal of Applied Corporate Finance, 16(4), 8-16.

Ihsan, H., \& Adnan, M. A. (2009a). Waqf accounting and the construction of accountability. In International Conference in Waqf Laws and Management: Reality and Prospects. Kuala Lumpur. Ihsan, H., \& Adnan, M. A. M. (2009b). Waqf accounting and the construction of accountability. International Conference in Waqf Laws and Management: Reality and Prospects, 27, 252-269. Ihsan, H., \& Ayedh, A. (2015). A proposed framework of Islamic governance for awqaf. Journal of Islamic Economics, Banking and Finance, 11(2), 117-132.

Ihsan, H., \& Ibrahim, S. H. H. M. (2011). WAQF accounting and management in Indonesian waqf institutions: The cases of two WAQF foundations. Humanomics, 27(4), 252-269.

KPMG International. (2011). Integrated Reporting: Performance insight through better business reporting.

Lewis, M. K. (2006). Accountability and Islam. In Fourth International Conference on Accounting and Finance in Transition (pp. 1-16).

Malaysian Accounting Standards Board. (2014). MASB Research Paper, Waqf. Kuala Lumpur. Mansor, N., Jamil, A., \& Bahari, A. (2018). Integrated Waqf Reporting System. International Journal of Accounting, Finance and Business (IJAFB), 2(6), 155-166.

Mansor, N., \& Mamat, I. (2017, June). UA perlu terajui perakaunan dana wakaf. Berita Harian. Masruki, R., Hanefah, M. M., Shafii, Z., Hamid, S. A., Laili, N. H., \& Kamaruddin, M. I. H. (2017). Best reporting practices for waqf: Performance, governance and socio-economic impact. MAREF Priority Research Topic.

Masruki, R., \& Shafii, Z. (2013). The development of waqf accounting in enhancing accountability. 
INTERNATIONAL JOURNAL OF ACADEMIC RESEARCH IN BUSINESS AND SOCIAL SCIENCES Vol. 8, No. 12, Dec, 2018, E-ISSN: 2222-6990 @ 2018 HRMARS

Middle-East Journal of Scientific Research 13 (Research in Contemporary Islamic Finance and Wealth Management), 13, 1-6.

Mohamad Suhaimi, F., Ab Rahman, A., \& Marican, S. (2014). The role of share waqf in the socioeconomic development of the Muslim community: The Malaysian experience. Humanomics, 30(3), 227-254.

Mohd Puad, B. N. A., Jamlus Rafdi, N. B., \& Shahar, W. S. S. B. (2014). Issues and Challenges of Waqf Instruments: A Case Study in MAIS. E-Proceedings of the Conference on Management and Muamalah, (May), 978-983.

Mustaffha, N., \& Zainal, M. F. (2016). Waqf and accounting treatment : Pursuing the transparency and accountability - A case study. In The 3rd International Conference on Masjid, Zakat and Waqf (IMAF 2016) (pp. 71-83). Shah Alam, Selangor, Malaysia.

Osman, A. F., Htay, S. N. N., \& Muhammad, M. O. (2012). Determinants of cash waqf giving in Malaysia: Survey of selected works. Workshop Antarbangsa Pembangunan Berteraskan Islam V (WAPI-5), 186-243.

Osman, A. Z. (2010a). Accountability of waqf management: Insight from praxis of NonGovernmental Organisation (NGO). In Seventh International Conference - The Tawhidi Epistemology: Zakat and Waqf Economy, Bangi (pp. 153-175).

Osman, A. Z. (2010b). Accountability of waqf management: Insight from praxis of nongovernmental organisation (NGO). In A. G. Ismail, M. E. M. Hassan, N. Ismail, \& S. Shahimi (Eds.), Seventh International Conference - The Tawhidi Epistemology: Zakat and Waqf Economy (pp. 154-175). Bangi: Institut Islam Hadhari, UKM.

Othman, R., \& Thani, A. M. (2010). Islamic social reporting of listed companies in Malaysia. International Business \& Economics Research Journal, 9(4), 135-144.

Perrini, F. (2006). The practitioner's perspective on non-financial reporting. California Management Review, 48(2), 73-103.

Perrini, F., \& Tencati, A. (2006). Sustainability and stakeholder management: The need for new corporate performance evaluation and reporting systems. Business Strategy and the Environment, 15(5), 296-308.

Ramli, A., Fahmi, F., Darus, F., \& Ismail, N. (2018). Primary drivers of sustainable performance: The case of corporate waqf. GJAT, January(Special Issue), 207-218.

Shafii, Z., Yunanda, R. A., \& Rahman, F. K. (2014). Financial and operational measures of waqf performance: The case of State Islamic Religion Council of Singapore and Malaysia.

Sinclair, A. (1995). The chameleon of accountability: Forms and discourses. Accounting, Organizations \& Society, 20 (2 \& 3), 219-237.

Siraj, S. A. (2012). An empirical investigation into the accounting, accountability and effectiveness of waqf management in the State Islamic Religious Councils (SIRCS) in Malaysia. Cardiff University.

Siraj, S. A., \& Karbhari, Y. (2014). Financial accountability of Waqf (Pious Endowment) Institutions in Malaysia: The case of budgeting practices in State Islamic Religious Councils.

Sulaiman, M., Adnan, M. A., \& Nor, P. N. S. M. M. (2009). Trust me! A case study of the International Islamic University Malaysia's Waqf Fund. Review of Islamic Economics, 13(1), 69-88. The Integrated Reporting Committee. (2011). Framework for integrated reporting and the integrated report: Discussion paper. 
The International Integrated Reporting Council. (2013). The international Integrated Reporting framework. The International $<\mid R>$ Framework.

Torres, L., \& Pina, V. (2003). Accounting for accountability and management in NPOs: A comparative study of four countries: Canada, the United Kingdom, the USA and Spain. Financial Accountability \& Management, 19(3), 265-285.

Yaacob, H., Petra, S., Sumardi, A., \& Nahar, H. S. (2013). Demonstrating accountability through accounting and reporting: Lessons from an awqaf institution operating in a non-Islamic South East Asia Country. In Paper Proceeding of the 5th Islamic Economics System Conference (iECONS 2013). Zain, S. R. M., Samad, R. N. A., \& Yusof, N. A. (2012). Waqf accounting practices by Malaysian Islamic Religious Councils. Social and Management Research Journal, 9(1), 55-72. 